\title{
Effects of Sub-Grade and Sub-Base Materials Quality on Flexible Pavement: A Case Study
}

\author{
Getu Tamiru, Palani Ponnurangam
}

Lecturer, Department of Civil Engineering, Mizan Tepi University, Tepi Campus, Ethiopia

\begin{abstract}
Flexible pavements are composed of asphaltic layer, base course; sub base materials which laid over a well compacted and strong sub grade foundation soil. Basic engineering properties of Sub grade materials are required for design and Coarse grained soils serves as good for supporting pavements whereas fine grained soils, particularly clayey soils pose problem to pavement. Jimma town is a big trade center and coffee production areas of in Ethiopia but, the current existing condition most parts of the road are deteriorated. The objective of this research was to investigate effects of subgrade and sub-base materials quality on flexible pavement.
\end{abstract}

The distress is categorized by level of severity according to Ethiopian Roads Authority (ERA) standard specification to get 4-stations high deterioration of block crack, 6-stations medium deterioration of Alligator crack and 5-stations low deterioration of edge crack of the studied stretch along Ajip to Gebrel church of $10 \mathrm{~km}$ in Jimma town. The samples taken randomly from the deteriorated area of the subgrade and sub-base materials of 15 stations and laboratory tests conducted and also the results were discussed, compared with the ERA, AASHTO and ASTM.

The tests result $\mathrm{NMC}>\mathrm{OMC}$ indicated that excess water in the subgrade and sub-base materials according to AASHTO D-180 specification, compaction of subgrade and sub-base layers are below the minimum requirement (MDD>97\% laboratory density) of AASHTO, poor strength $(\mathrm{CBR}<1.76 \mathrm{gm} / \mathrm{cc})$ of AASHTO T-193 and ERA specification, sieve analysis for gradation out of the upper and lower limit of AASHTO T-27 for the subgrade and sub-base materials. These can be causes of pavement deterioration on flexible pavement. But, the Atterberg's limit test results satisfy the standard specification of ASTM D-4318.

From this research recommended that the designer and contractor should be follow the minimum requirement set by standard specification regarding the engineering properties of materials, the side ditch must be constructed so as to prevent infiltration of water to the under lining strata, seal coats shall be applied to prevent infiltration of water through cracked surfaces to subgrade layer of the pavement.

Keyword: Deterioration, Distress, Moisture Content, Pavement, Sub-base and Subgrade.

\section{INTRODUCTION}

Asphalt pavements designed and constructed properly for the roads deliver a smooth, quiet, and durable solution. The success of any asphalt pavement is depending on the construction materials being designed for its environment, construction methodology and drainage and workmanship. The main structural function of pavement are to support the wheel loads applied to the carriage way and ultimately distribute to the subgrade layer. The major problem of flexible pavements were not being designed and constructed to sufficiently long lasting and cost effective. It reflects problems like early cracking, rutting and moisture damage.

This research was conducted on Jimma city. This is a big trade center in south western part of Ethiopia where people from different direction comes to the city for business exchange. Besides these Jimma Zone is one of the country's coffee production areas. Hence this coffee product is mostly packed and loaded to the center of country from warehouses found in Jimma town. Pavement deterioration mostly occurs in poor 
(unsuitable) construction of the subgrade and sub-base materials. This permanent deterioration in a welldesigned pavement is fairly load distributed between the pavement layers of materials.

In Ethiopia, Road deterioration could be in the form of cracks, potholes, surface deformation, and surface defects which makes unsafe the road network and unsuitable to the road users. For the effect of result to loss of lives, properties and human injuries through accidents, retardation of the rate of economic growth and development in affected areas, environmental pollution and degradation, impedance of human movement and the flow of economic activities and numerous cases of armed rob by attacks along affected area. These effects need to investigate on effects of subgrade and sub base materials quality on flexible pavement: A case study along Ajip to Gebrel of Jimma town.

\section{STUDY AREA}

The research was conducted at Jimma Zone of Oromia region in Ethiopia. This located in $346 \mathrm{~km}$ from south west of capital city of Ethiopia (Addis Ababa). It has latitude and longitude of $7^{0} 40^{\prime} \mathrm{N}$ to $7^{0}$ $45^{\prime} \mathrm{N}, 36^{\circ} 50 \mathrm{E}$ to $36^{\circ} 45^{\prime} \mathrm{N}$ and total population about 220, 573. Investigations were carried out along Ajip to Gebrel Church of Jimma town which is $10 \mathrm{~km}$ and more attention to the deteriorated stations of the study stretch of existing road.
Average elevation of the studied area is $1,700 \mathrm{~m}$ above mean sea level and the topography is flat and rolling. The climate of the area is moderate temperature and rainfall. The mean annual temperature of the area is $18^{\circ} \mathrm{C}$. The mean annual rainfall ranges 800 to $1200 \mathrm{~mm}$. The major dominate rocks are naturally light in color and highly susceptible to physical and chemical weathering and the major dominant types of soils of the town are clay soil.

Drainage is one of the major problems in Jimma city. In some sections of the road shallow earth ditches are available. On the other hand there is no drainage structure which facilitates flow of water alongside of road. Most of observed drainage structures are currently under poor condition both structurally and functionally. The city has natural flood problem which have negative impact on existing pavement.

\section{RESEARCH DESIGN}

The study was analyzed in relation to theoretical propositions. The overall approach was six stages process: Identified the types of distress of studied stretch, categorized by level of severity (high, medium and low), necessary sample extracted by using random sampling method of the distress stations and conducted in the laboratory and the laboratory test results are compared with the standard specification and finally conclusions and recommendations have been made based on the findings.

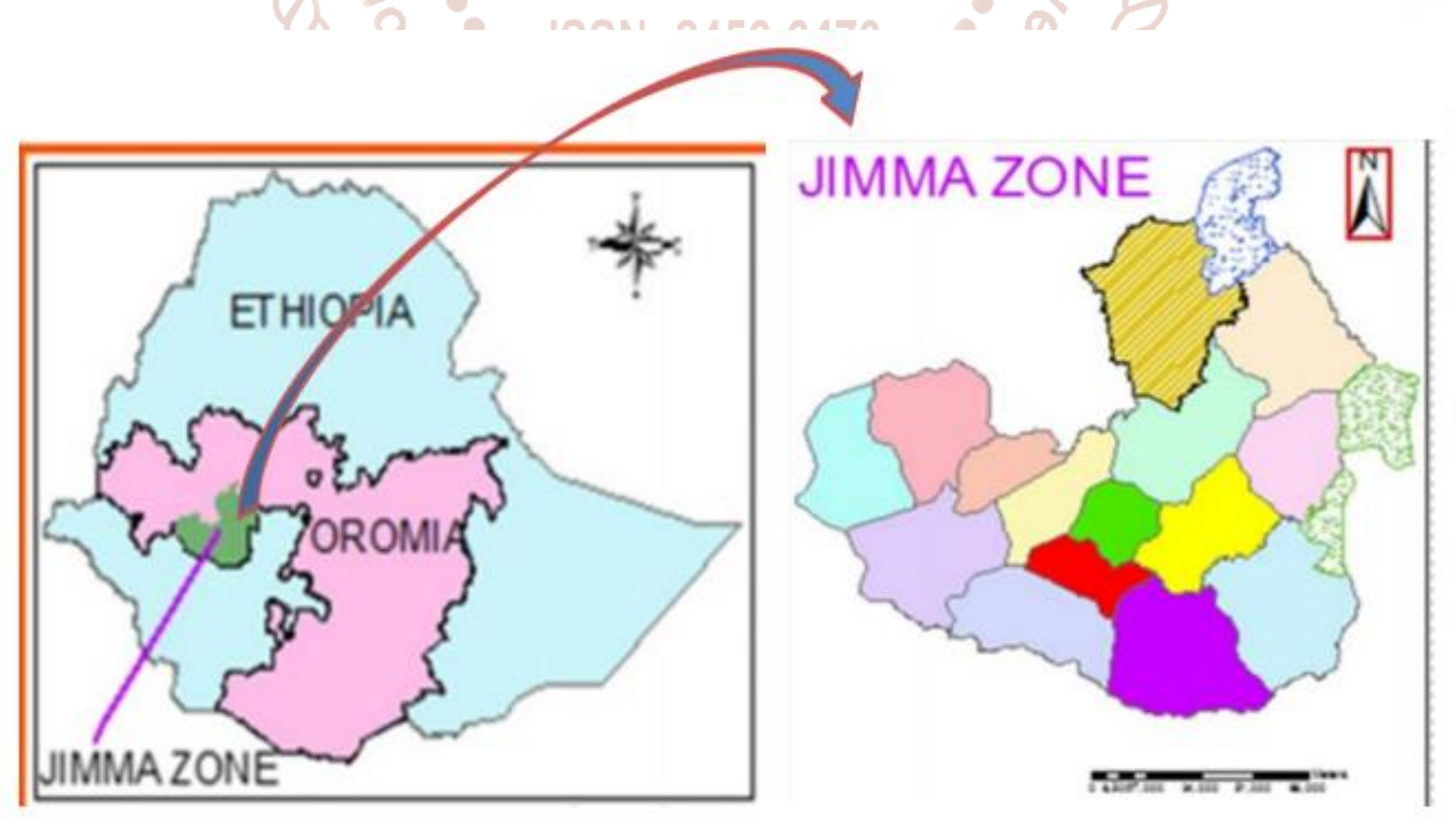

Fig 1: Location of Jimma zone 
International Journal of Trend in Scientific Research and Development (IJTSRD) ISSN: 2456-6470

\subsection{Study Procedure}

$>$ To identify the distress along study stretch (block cracking, alligator cracking and edge cracking).

$>$ To categorize according to ERA standard specification of 4-stations high deteriorations of block cracking, 6-stations medium deterioration of alligator cracking and 5-Stations low deterioration of edge cracking.

$>$ The Samples extracted by random sampling method of the distress stations.

$>$ The laboratory tests conducted (Natural moisture content, Atterberg's limit, Compaction, Sieve analysis and California bearing ratio).

$>$ The results are discussed compared with standard specification of ERA, AASHTO and ASTM.
$>$ Conclusions would be developed and recommended appropriate remedial measure towards sustainable solution.

\subsection{Sample size and Data collection process}

In order to generate data for the general and specific objective, field survey and laboratory test were carried out on distress stations. The researcher first identified the distress and categorized by level of severity (high, medium and low deterioration). Collect the primary data of samples were taken from subgrade and subbase materials of the deteriorated flexible pavement along Ajip to Gebrel church of Jimma town in Ethiopia.

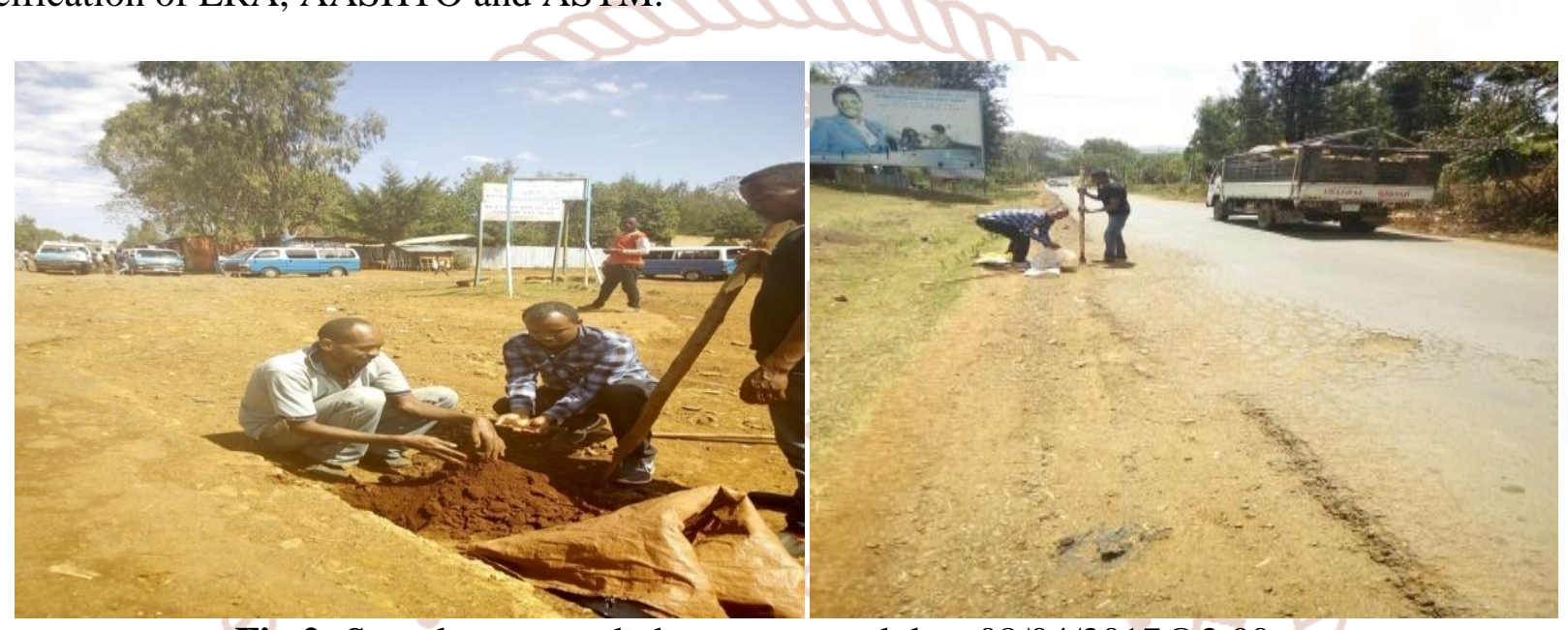

Fig 2: Sample extracted photos captured date 08/04/2017@3:00p.m

Quantitative and qualitative data utilized based on the necessarily input parameters for analysis and compare with ERA, AASHTO and ASTM specification manuals. Data collection process included but not limited to: reviewing letter for correspondence reports, design documents, field visual inspection and inventory, identified the type of distress (edge cracking, block cracking and alligator cracking), categorized by level of severity (5low deteriorated stations of edge cracking, 4-high deteriorated stations of block cracking and 6-medium deteriorated stations of alligator cracking) by ERA (2002), samples extracted from the deteriorated area.

Field observation was necessary to begin by site visit was taken on the whole portion of roads and at the same time identifies the type of distresses of studied stretch (Ajip to Gebrel church).Then, categorized by level of severity by ERA manual, samples were taken from the studied stretch for distress stations of subgrade and sub base materials for laboratory test a total length of $10 \mathrm{~km} .15$ samples extracted for subgrade and sub base layer of the distress stations, 200kgs from high deterioration, 400kgsfrom medium deterioration and $300 \mathrm{kgs}$ from low deterioration were collected samples were tested in the laboratory.

By random sampling technique was used by Samples extracted from the deteriorated area of sub-base and subgrade materials to make it sure as the engineering parameters had certain characteristics as applied for this study.

\subsection{Laboratory test}

Sample extracted and laboratory performed are Atterbegs limit (for comparison and determination of liquid limit and plastic limit), Grain size analysis (distribution of particle size analysis), compaction test (for determination of maximum dry density and optimum moisture contents), California Bearing ratio (CBR) test 
International Journal of Trend in Scientific Research and Development (IJTSRD) ISSN: 2456-6470

(for Determine of shear strength of materials), Natural moisture content (percentage of water by dry soil). The tests are performed according to AASHTO, ERA and ASTM specification.

\subsubsection{Grain size Analysis Test}
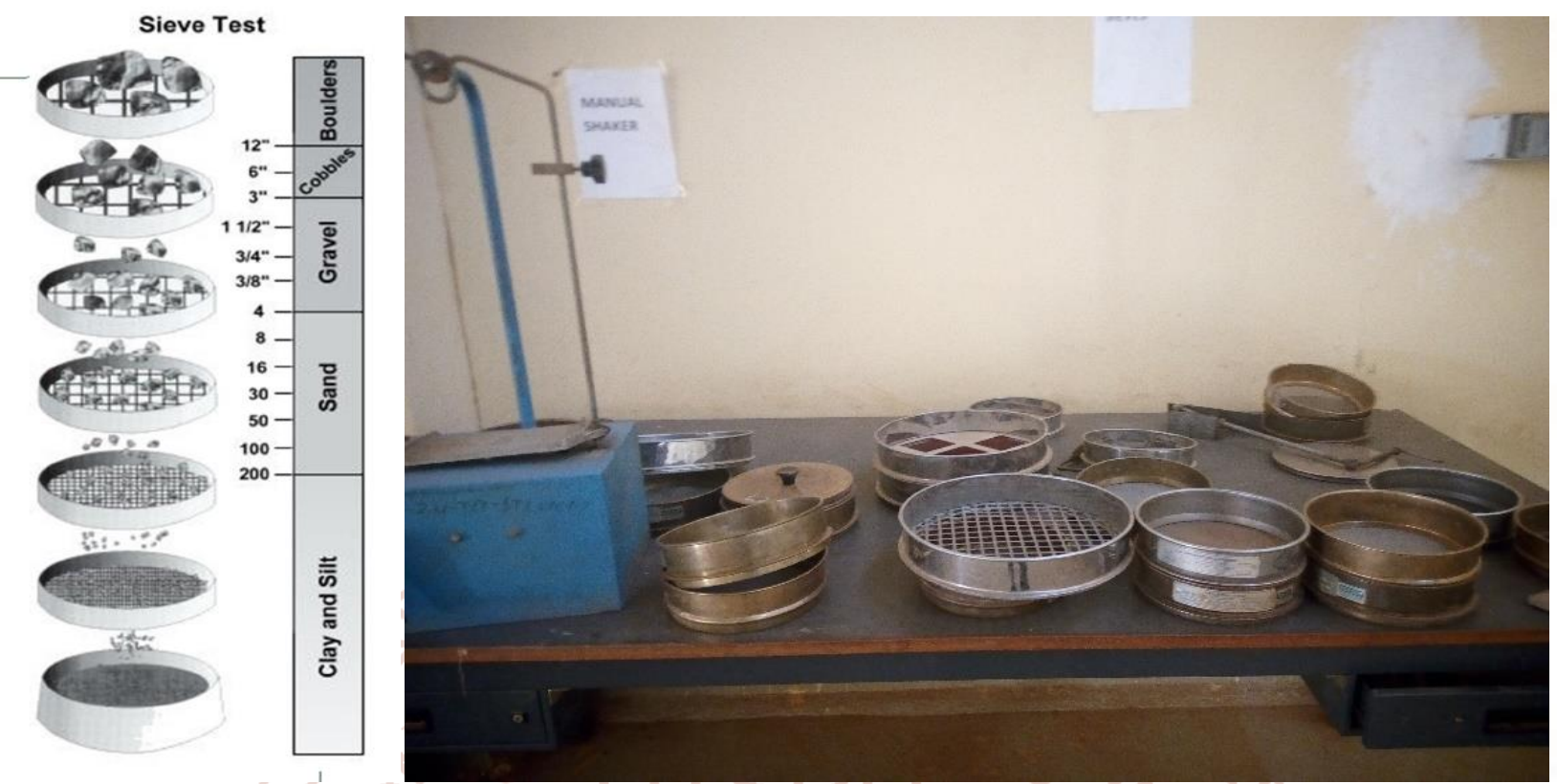

Fig 3: Apparatuses for grain size analysis test

Purpose: To determine the grain size distribution curve of soil samples and is useful for soil fraction larger than $75 \mu \mathrm{m}$.

Apparatus: Series of standard sieves (for gravel fraction 4.75-75mm aperture size, and for sand fraction 0.075$2 \mathrm{~mm}$ aperture size), Lid (cover), Pan (receiver), sieve shaker, Balance sensitive to 0.1g, Soft wire brush, Sample splitter, Mortar, and rubber-covered pestle for breaking up aggregates of soil particles, Oven.

\subsubsection{Compaction Test}
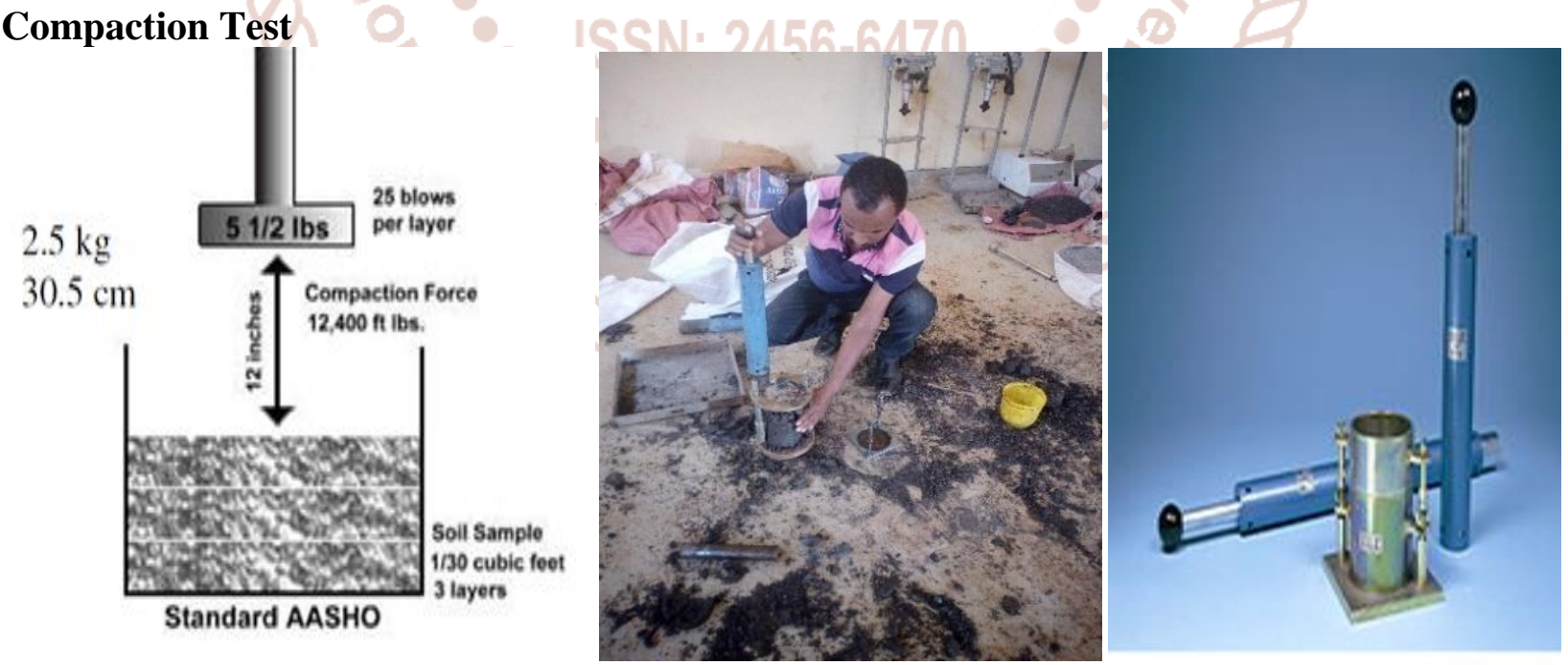

Fig 4: Apparatuses for compaction test

Purpose: To get the maximum dry density (MDD) for the soil and optimum moisture content (OMC).

Apparatus: mold, compaction with full accessories (hummer $2.5 \mathrm{~kg}$ ) and Oven dry machine 


\subsubsection{Atterberg's limit test}

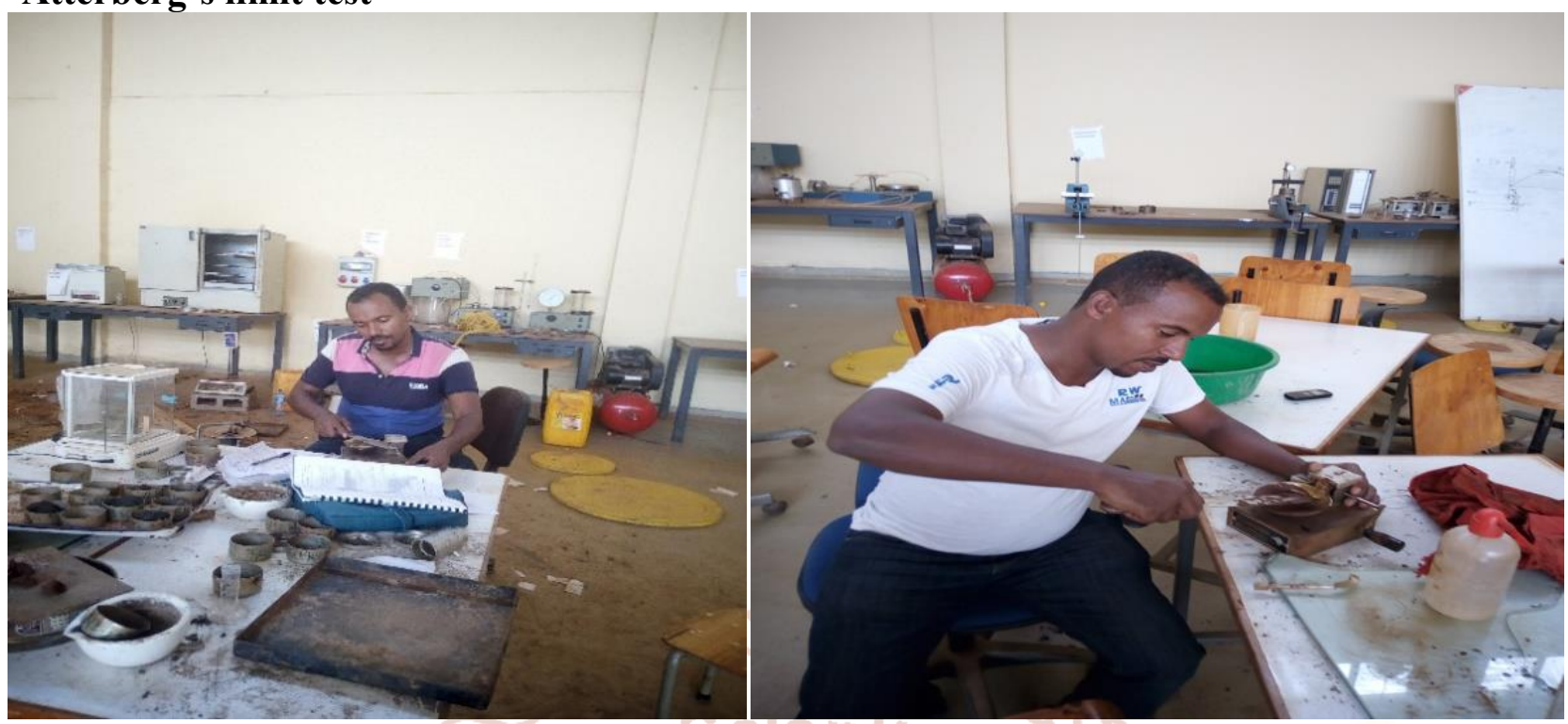

Fig 5: Apparatuses for atterberg's limit test

Purpose: To measure the plasticity and shrinkage nature of the soil.

Apparatus: Grooving tools, Casagrande, tools and spatula.

\subsubsection{Natural moisture content test}

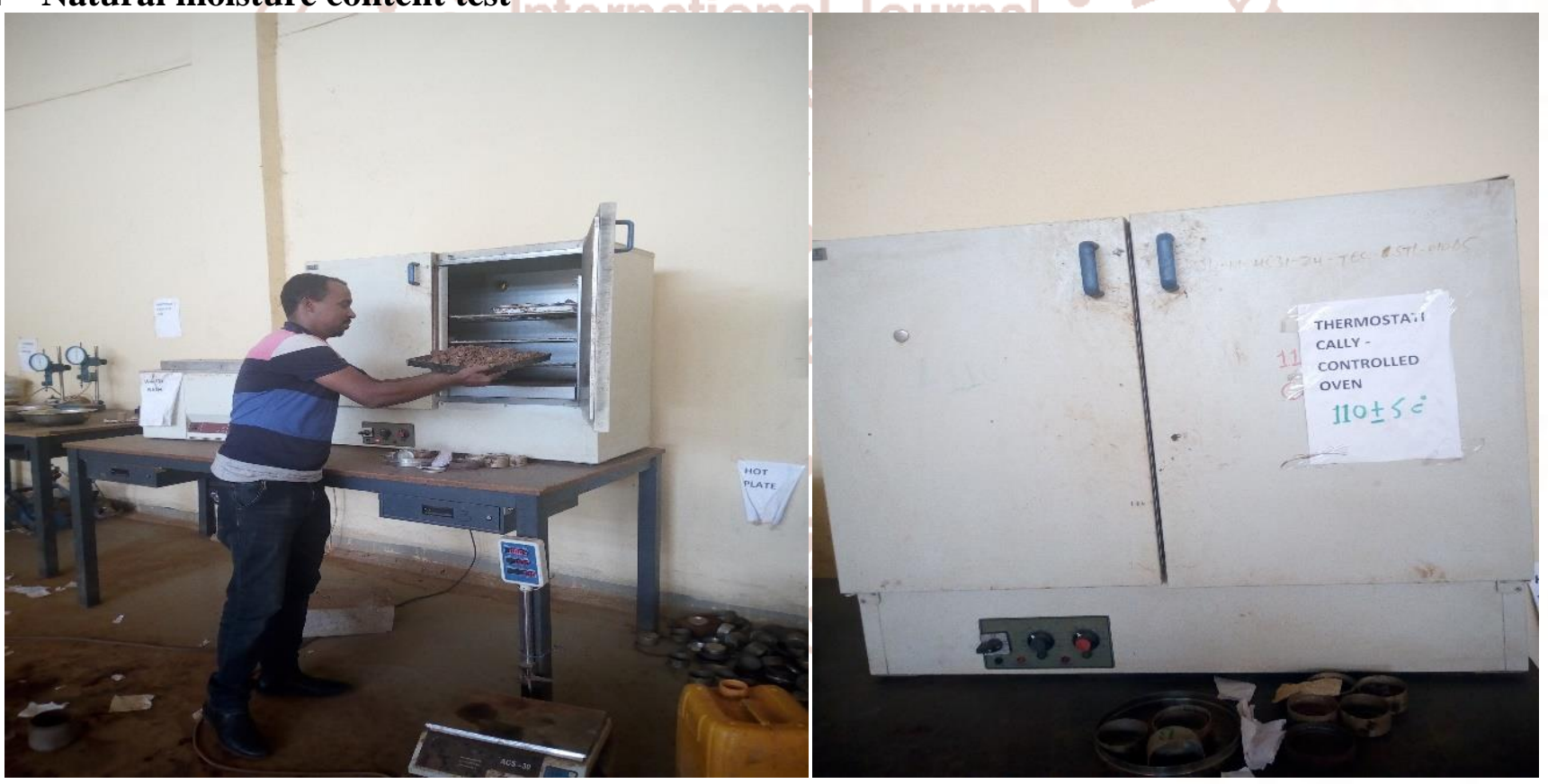

Fig 6: Apparatuses for natural moisture content test

Purpose: The amount of water exists in a given subgrade and sub-base materials mass.

Apparatus: Sampling trey, weight balance and Oven dry machine

\subsubsection{California Bearing Ratio (CBR)}

Purpose: To determine the shear strength of subgrade and sub-base materials.

Apparatus: Mold, a separate base plate, an extension collar and a spacer disc. 

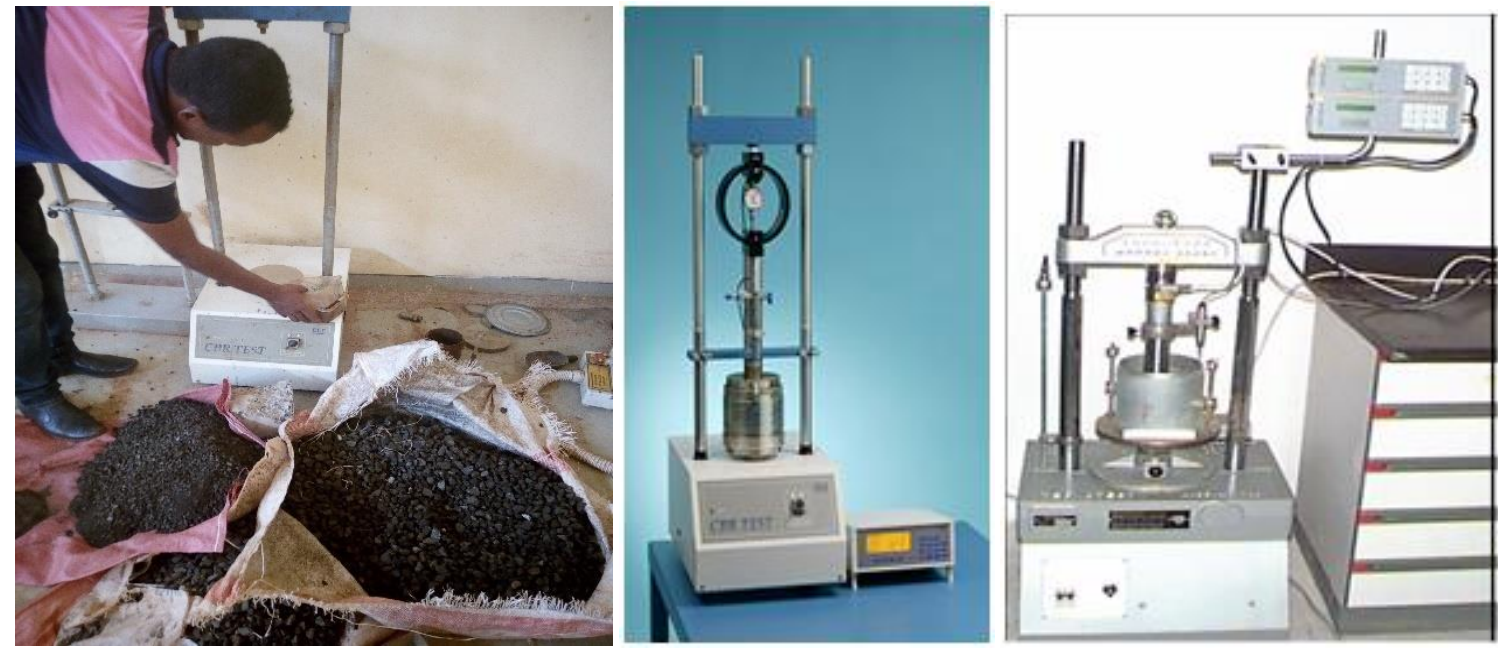

Fig 7: Apparatuses for CBR test

\section{RESULTS AND DISCUSSIONS}

These study sections were observed 4-stations block crack of high deterioration (more severe), 6-stations alligator crack of medium deterioration (severe) and 5-stations edge crack of low deterioration (low severe).Level of severity (damage) is classified by ERA manual, depend upon length, depth and width of the crack. These measured by using Tape meter.

Table 1: Distress details along the study stretch

\begin{tabular}{|c|c|c|c|c|c|}
\hline Section & Stn & $\begin{array}{l}\text { Location } \\
\text { (GPS) }\end{array}$ & Distress Types & $\begin{array}{c}\text { Level of Damage (Severity) } \\
\text { ERA } 2002\end{array}$ & Distress Direction \\
\hline \multirow{3}{*}{$\begin{array}{l}\text { Section }-1 \\
(0-2 \mathrm{~km})\end{array}$} & $0+020$ & $\begin{array}{c}N=0567853 \\
E=0969637 \\
Z=1218\end{array}$ & Alligator crock & $\begin{array}{l}\text { Medium deterioration (Severity) } \\
\text { reh and }\end{array}$ & Left side \\
\hline & $0+920$ & $\begin{array}{c}\mathrm{N}=0567852 \\
\mathrm{E}=0969639 \\
\mathrm{Z}=1219\end{array}$ & Block crack & High deterioration (More sever) & Center \\
\hline & $1+840$ & $\begin{array}{c}N=0567856 \\
E=0969638 \\
Z=1217\end{array}$ & Edge crack & $\begin{array}{c}\text { Low deterioration } \\
\text { (Low severe) }\end{array}$ & Right side \\
\hline \multirow{3}{*}{$\begin{array}{l}\text { Section }-2 \\
(2-4 \mathrm{~km})\end{array}$} & $2+160$ & $\begin{array}{c}N=0566782 \\
E=0968827 \\
Z=1219\end{array}$ & Edge crack & $\begin{array}{c}\text { Low deterioration } \\
\text { (Low severe) }\end{array}$ & Left side \\
\hline & $3+160$ & $\begin{array}{c}N=0566784 \\
E=0968829 \\
Z=1218\end{array}$ & Alligator crack & $\begin{array}{l}\text { Medium deterioration } \\
(\text { Severe })\end{array}$ & Both side \\
\hline & $3+740$ & $\begin{array}{c}N=0566781 \\
E=0968827 \\
Z=1217\end{array}$ & Block crack & $\begin{array}{l}\text { High deterioration } \\
\text { (more severe) }\end{array}$ & Center \\
\hline \multirow{3}{*}{$\begin{array}{l}\text { Section }-3 \\
(4-6 \mathrm{~km})\end{array}$} & $4+240$ & $\begin{array}{c}N=0566785 \\
E=0968827 \\
Z=1218\end{array}$ & Alligator crack & $\begin{array}{l}\text { Medium deterioration } \\
\text { (Severe) }\end{array}$ & Both \\
\hline & $4+300$ & $\begin{array}{c}\mathrm{N}=0566787 \\
\mathrm{E}=0968826 \\
\mathrm{Z}=1219\end{array}$ & Edge crack & $\begin{array}{l}\text { Low deterioration } \\
\text { (Low severe) }\end{array}$ & Right side \\
\hline & $5+500$ & $\begin{array}{c}N=0566789 \\
E=0968827 \\
Z=1220\end{array}$ & Alligator crack & $\begin{array}{l}\text { Medium deterioration } \\
\text { (Severe) }\end{array}$ & Both \\
\hline
\end{tabular}


International Journal of Trend in Scientific Research and Development (IJTSRD) ISSN: 2456-6470

\begin{tabular}{|c|c|c|c|c|c|}
\hline \multirow{3}{*}{$\begin{array}{l}\text { Section }-4 \\
(6-8 \mathrm{~km})\end{array}$} & $6+720$ & $\begin{array}{c}N=0567851 \\
E=0969637 \\
Z=1221\end{array}$ & Block crack & $\begin{array}{l}\text { High deterioration } \\
\text { (more Severe) }\end{array}$ & Center \\
\hline & $7+740$ & $\begin{array}{c}\mathrm{N}=0567853 \\
\mathrm{E}=0969638 \\
\mathrm{Z}=1220\end{array}$ & Alligator crack & $\begin{array}{l}\text { Medium deterioration } \\
\text { (Severe) }\end{array}$ & Both side \\
\hline & $7+820$ & $\begin{array}{c}N=0567854 \\
E=0967636 \\
Z=1219\end{array}$ & Edge crack & $\begin{array}{l}\text { Low deterioration } \\
\text { (Low severe) }\end{array}$ & Left side \\
\hline \multirow{3}{*}{$\begin{array}{l}\text { Section } 5 \\
(8-10 \mathrm{~km})\end{array}$} & $9+140$ & $\begin{array}{c}N=0568119 \\
E=0968834 \\
Z=1220\end{array}$ & Edge crack & High deterioration & Left side \\
\hline & $9+420$ & $\begin{array}{c}N=0568121 \\
E=0968830 \\
Z=1221\end{array}$ & Block crock & $\begin{array}{l}\text { High deterioration } \\
\text { (More severe) }\end{array}$ & Center \\
\hline & $9+720$ & $\begin{array}{c}\mathrm{N}=0568122 \\
\mathrm{E}=0968632 \\
\mathrm{Z}=1222\end{array}$ & Alligator crack & $\begin{array}{l}\text { Medium deterioration } \\
\text { Q (Severe) }\end{array}$ & Both \\
\hline
\end{tabular}

Table 2: Categorized by level of severity along the study stretch

\begin{tabular}{|c|c|c|c|c|c|}
\hline \multirow[b]{2}{*}{$\begin{array}{l}\text { Type of } \\
\text { distress } \\
\text { (cracking) }\end{array}$} & \multirow[b]{2}{*}{$\begin{array}{l}\text { Level of } \\
\text { Deterioration(severity) } \\
\text { for degree of distress }\end{array}$} & \multicolumn{4}{|c|}{ Measure the distress pavement } \\
\hline & & $\begin{array}{l}\text { Average } \\
\text { Length } \\
\text { (m) }\end{array}$ & $\begin{array}{c}\text { A verage } \\
\text { Diameter (width) } \\
\text { of Distress } \\
(\mathrm{cm})\end{array}$ & $\begin{array}{l}\text { A verage } \\
\text { Depth of } \\
\text { distress } \\
\text { (cm) }\end{array}$ & $\begin{array}{c}\text { ERA } \\
\text { Standard } \\
\text { specification of } \\
\text { severity ( standard) }\end{array}$ \\
\hline $\begin{array}{c}\text { Block } \\
\text { cracking }\end{array}$ & High & 0.78 & $\begin{array}{l}4 \\
52\end{array}$ & 50 & $\begin{array}{l}\text { (Length } \times \text { Width }) \\
>(50 \mathrm{~cm} \times 50 \mathrm{~cm})\end{array}$ \\
\hline $\begin{array}{l}\text { Alligator } \\
\text { cracking }\end{array}$ & Medium & & 28.67 & 50 & $\begin{array}{c}>15 \mathrm{~cm} \text { Diameter of } \\
\text { distress }\end{array}$ \\
\hline $\begin{array}{c}\text { Edge } \\
\text { cracking }\end{array}$ & Low & 17.41 & 34.84 & & $\begin{array}{c}>17 \mathrm{~cm} \text { width of } \\
\text { distress }\end{array}$ \\
\hline
\end{tabular}

Grain size Analysis: At the whole stretch of the road of sub base and subgrade materials were used performed on laboratory test and the results showed for the samples have been tested were out of Minimum and maximum range limit of AASHTO T-27 standard specification. Which implies those have been constructed was not uniformly graded at all. The detail results are attached in appendix A.

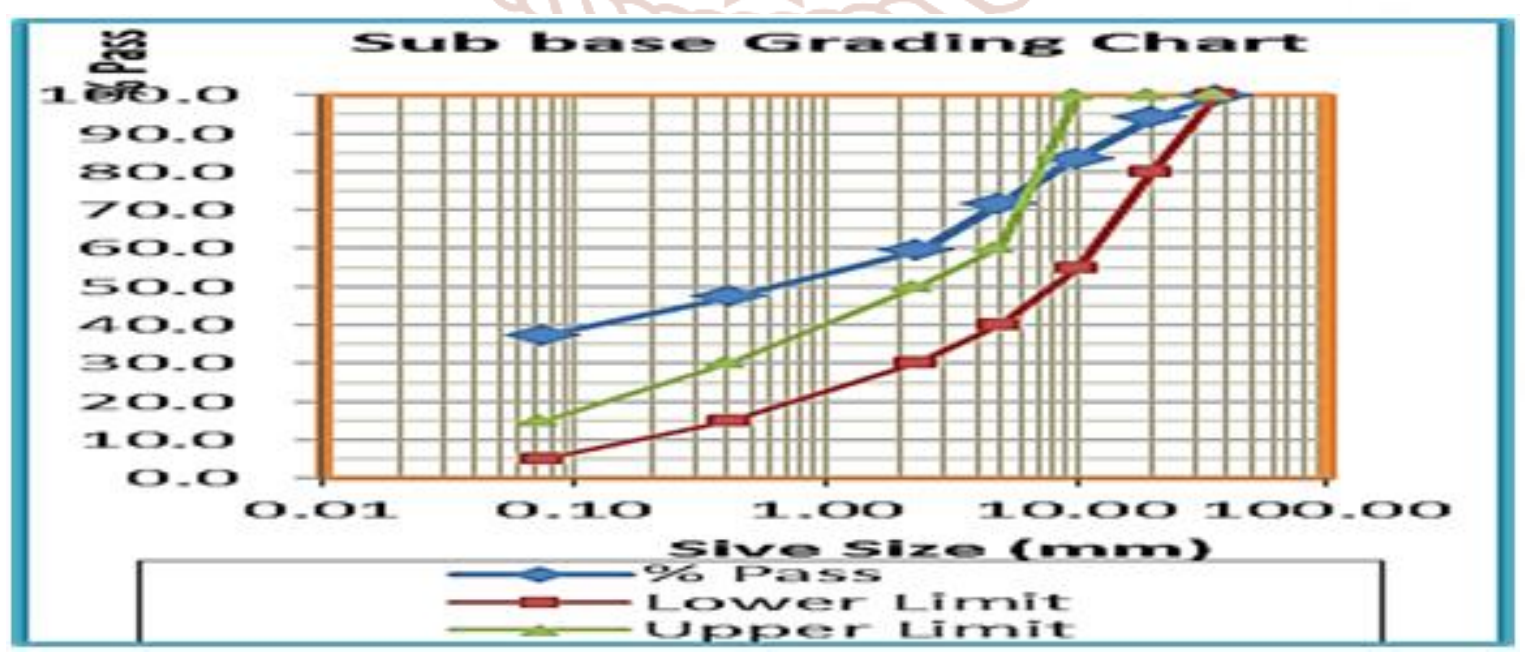




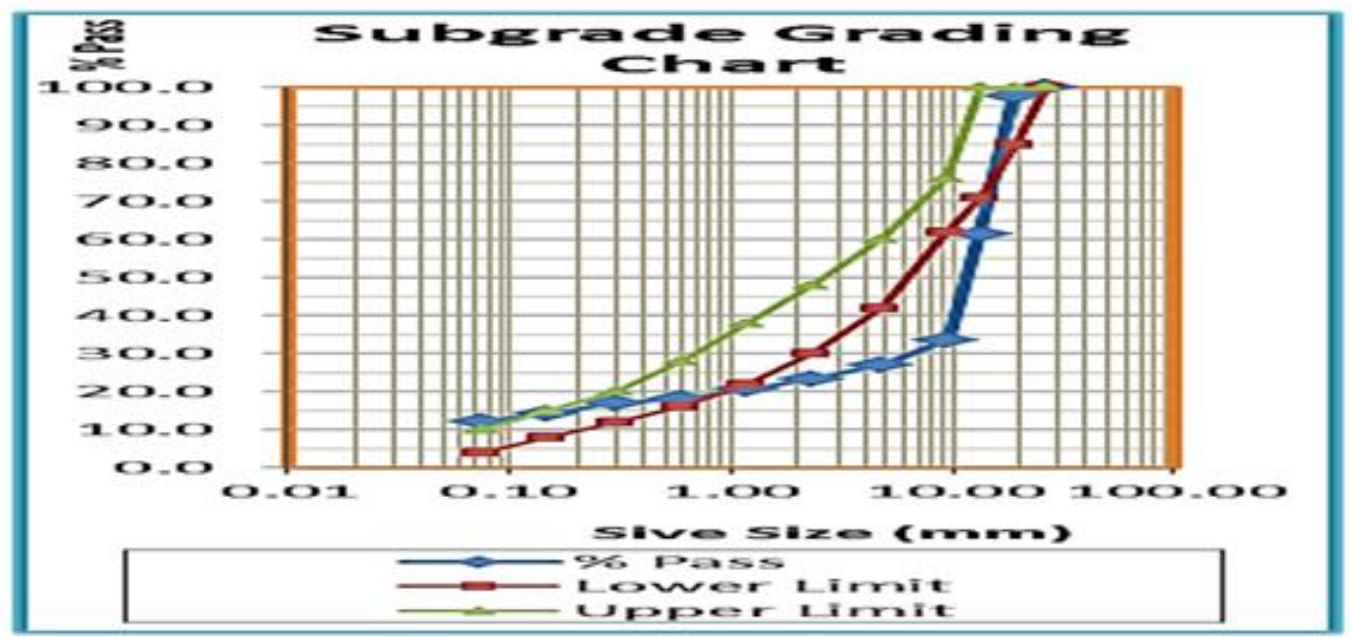

Fig 8: Laboratory test result for the grain size analysis of sub base

Figure 8 depicts that laboratory test result for the grain size analysis of sub base At all sample stations it is out of minimum and maximum limit of AASHTO T-11 Standard specification (the material passing $0.075 \mathrm{~mm}$ sieve size by sieve analysis method) which implies not uniformly graded (poor graded). It was observed that the gradation of the sub-grade and the sub-base materials was not within the recommended range (out of the range).

\section{Atterberg's limit}

Table 3: Atterberg's limit test results

\begin{tabular}{|c|c|c|c|c|c|c|c|}
\hline \multirow[b]{2}{*}{$\begin{array}{l}\text { Level of } \\
\text { damage } \\
\text { (severe) }\end{array}$} & \multirow[b]{2}{*}{ Station } & \multicolumn{3}{|c|}{ Sub-grade materials } & \multicolumn{3}{|c|}{ Sub-base materials } \\
\hline & & $\begin{array}{l}\text { Liquid } \\
\text { limit } \\
\text { (LL) }\end{array}$ & $\begin{array}{l}\text { Plastic } \\
\text { limit } \\
(\mathrm{PL})\end{array}$ & $\begin{array}{l}\text { Plasticity } \\
\text { Index (PI) }\end{array}$ & $\begin{array}{l}\text { Liquid } \\
\text { Limit } \\
\text { (LL) }\end{array}$ & $\begin{array}{l}\text { Plastic } \\
\text { Limit } \\
\text { (PL) }\end{array}$ & $\begin{array}{l}\text { Plasticity } \\
\text { Index (PI) }\end{array}$ \\
\hline \multirow{5}{*}{$\begin{array}{c}\text { High } \\
\text { deterioration } \\
\text { (More severe) }\end{array}$} & $0+920$ & 67.15 & $32.41 \mathrm{c}$ & C 34.740 & 38.16 & 27.12 & 11.04 \\
\hline & $3+740$ & 62.14 & 34.82 & 27.32 & 43.140 & 28.46 & 14.68 \\
\hline & $6+720$ & 60.70 & 32.82 & 27.89 & 42.78 & 29.16 & 13.62 \\
\hline & $9+420$ & 68.84 & 35.07 & 33.77 & 39.15 & 29.68 & 9.47 \\
\hline & Average & 64.71 & 37.78 & 5030.930 & 40.81 & 28.61 & 12.20 \\
\hline \multirow{7}{*}{$\begin{array}{c}\text { Medium } \\
\text { deterioration } \\
(\text { Severe })\end{array}$} & $0+020$ & 55.09 & 28.74 & 26.35 & 34.08 & 25.63 & 8.45 \\
\hline & $3+160$ & 57.63 & 29.84 & 27.79 & 33.71 & 26.18 & 7.53 \\
\hline & $4+240$ & 53.95 & 30.16 & 23.79 & 30.89 & 24.73 & 6.16 \\
\hline & $5+500$ & 51.81 & 31.09 & 20.72 & 32.92 & 26.19 & 6.73 \\
\hline & $7+740$ & 52.07 & 30.74 & 21.33 & 35.01 & 25.82 & 9.19 \\
\hline & $9+720$ & 55.71 & 31.88 & 23.83 & 31.93 & 27.01 & 4.92 \\
\hline & Average & 54.38 & 30.41 & 23.97 & 33.09 & 25.93 & 7.16 \\
\hline \multirow{6}{*}{$\begin{array}{c}\text { Low } \\
\text { deterioration } \\
\text { (Low severe) }\end{array}$} & $1+840$ & 51.71 & 28.55 & 23.16 & 24.88 & 22.35 & 2.53 \\
\hline & $2+160$ & 50.89 & 25.92 & 24.97 & 28.16 & 23.81 & 4.35 \\
\hline & $4+300$ & 50.14 & 26.67 & 23.47 & 30.43 & 20.98 & 9.45 \\
\hline & $7+820$ & 50.65 & 28.16 & 22.49 & 30.11 & 21.65 & 8.45 \\
\hline & $9+140$ & 50.12 & 27.05 & 23.07 & 27.81 & 21.87 & 5.94 \\
\hline & Average & 50.70 & 27.27 & 23.43 & 28.27 & 22.13 & 6.14 \\
\hline \multicolumn{2}{|c|}{ Total Average } & 56.59 & 31.82 & 24.77 & 33.85 & 25.89 & 7.96 \\
\hline
\end{tabular}

The Laboratory test results, it could be seen that the sub-grade and sub-base materials average liquid limits are 56.59 and 33.85 and average plasticity Index 24.77 and 7.96 respectively. The sub-base LL and PI of the ASTM D 4318 specified value are LL $\leq 45 \%$ and $\mathrm{PI} \leq 12 \%$ and sub-grade LL $\leq 80 \%$ and $\mathrm{PI} \leq 55 \%$ in general the average value of PI for sub-base and sub-grade with is the recommended specification. Both sub-base and subgrade materials are satisfy the requirement. 
International Journal of Trend in Scientific Research and Development (IJTSRD) ISSN: 2456-6470

\section{Natural moisture content}

Table 4: Natural moisture content test results

\begin{tabular}{|c|c|c|c|}
\hline \multirow{2}{*}{ Level of Damage (severe) } & \multirow{2}{*}{ Station } & \multicolumn{2}{|c|}{ Natural moisture content (\%) } \\
\hline & & Sub-grade layers & Sub base layer \\
\hline \multirow{5}{*}{$\begin{array}{l}\text { High deterioration } \\
\text { (More severe) }\end{array}$} & $0+920$ & 39.32 & 18.67 \\
\hline & $3+740$ & 38.67 & 14.91 \\
\hline & $6+720$ & 33.71 & 17.74 \\
\hline & $9+420$ & 34.45 & 15.65 \\
\hline & Average & 36.76 & 15.08 \\
\hline \multirow{7}{*}{$\begin{array}{l}\text { Medium deterioration } \\
\text { (Severe) }\end{array}$} & $0+020$ & 20.34 & 15.72 \\
\hline & $3+160$ & 20.15 & 13.11 \\
\hline & $4+240$ & 38.82 & 10.01 \\
\hline & $5+500$ & 39.43 & 13.98 \\
\hline & $7+740$ & 38.97 & 12.34 \\
\hline & $9+720$ & 39.65 & 12.58 \\
\hline & Average & 32.44 & 32.27 \\
\hline \multirow{6}{*}{ Low deterioration (Low severe) } & $1+840$ & 27.52 & 28.42 \\
\hline & $2+160$ & 27.94 & 28.81 \\
\hline & $4+300$ & 26.98 & 27.93 \\
\hline & $7+820$ & 27.05 & 28.77 \\
\hline & $9+140$ & 28.74 & 27.63 \\
\hline & Average & 27.64 & 28.31 \\
\hline Total Average & btione & 32.28 & 25.22 \\
\hline
\end{tabular}

The average natural moisture content (NMC) test of subgrade and sub base materials obtained from the laboratory more deterioration, medium deterioration and less deterioration are $36.76 \%, 32.44 \%, 27.64 \%$ and $15.08 \%, 32.27 \%, 28.31 \%$ respectively and optimum moisture content (OMC) of AASHTO D-180standard specification of the subgrade and the sub base materials are $30.05 \%, 12.06 \%, 11.08 \%$ and $14.44 \%, 30.44 \%$, $26.06 \%$ respectively. MC>OMC.

\section{Compaction (Moisture - density relation)}

The relation between maximum dry densities MDD Vs Optimum moisture content (OMC) of the selected stretch.

Table 5: Compaction test results

\begin{tabular}{|c|c|c|c|c|c|}
\hline \multirow{2}{*}{ Level of Damage (severe) } & \multirow{2}{*}{ Station } & \multicolumn{2}{c|}{ Sulb grade layers } & \multicolumn{2}{c|}{ Sub base Layers } \\
\cline { 2 - 6 } & & OMC (\%) & MIDD (g/cc) & OMC (\%) & MDD (g/cc) \\
\hline \multirow{4}{*}{$\begin{array}{c}\text { High deterioration } \\
\text { (More severe) }\end{array}$} & $0+920$ & 35.12 & 1.27 & 14.52 & 1.72 \\
\cline { 2 - 6 } & $3+740$ & 34.86 & 1.29 & 14.11 & 1.84 \\
\cline { 2 - 6 } & $6+720$ & 32.80 & 1.31 & 14.46 & 1.65 \\
\cline { 2 - 6 } & $9+420$ & 37.24 & 1.28 & 14.67 & 1.82 \\
\cline { 2 - 6 } & Average & 35.01 & 1.29 & 14.44 & 1.76 \\
\hline \multirow{5}{*}{ Medium deterioration } & $0+020$ & 30.92 & 1.32 & 11.90 & 1.73 \\
\cline { 2 - 6 } & $3+160$ & 31.46 & 1.36 & 12.80 & 1.79 \\
\cline { 2 - 6 } & $4+240$ & 30.76 & 1.29 & 11.97 & 1.86 \\
\cline { 2 - 6 } & $5+500$ & 31.01 & 1.25 & 12.56 & 1.52 \\
\cline { 2 - 6 } & $7+740$ & 29.82 & 1.26 & 11.46 & 1.51 \\
\cline { 2 - 6 } & $9+720$ & 28.68 & 1.30 & 11.62 & 1.82 \\
\cline { 2 - 6 } & Average & 30.44 & 1.30 & 12.06 & 1.71 \\
\hline \multirow{3}{*}{ Low detere) } & $1+840$ & 26.31 & 1.31 & 8.13 & 1.96 \\
\cline { 2 - 6 } & $2+160$ & 25.45 & 1.26 & 7.14 & 1.98 \\
\cline { 2 - 6 } & $4+300$ & 24.97 & 1.22 & 6.98 & 1.92 \\
\hline
\end{tabular}


International Journal of Trend in Scientific Research and Development (IJTSRD) ISSN: 2456-6470

\begin{tabular}{|c|c|c|c|c|c|}
\hline \multirow{2}{*}{ Total Average $=$} & $7+820$ & 26.42 & 1.32 & 6.50 & 1.97 \\
\cline { 2 - 6 } & $9+140$ & 27.15 & 1.35 & 5.02 & 1.93 \\
\cline { 2 - 6 } & Average & 26.06 & 1.29 & 6.75 & 1.95 \\
\hline & 30.50 & 1.29 & 11.08 & 1.81 \\
\hline
\end{tabular}

The sub-grade soil samples were subjected to the determination of maximum dry density (MDD) and optimum moisture content (OMC) in the Laboratory. The Laboratory test result reveals that the range of maximum dry density of the sub-grade and sub base materials lies in the range of $1.22 \mathrm{~g} / \mathrm{cc}-1.36 \mathrm{~g} / \mathrm{cc}$ and $1.51 \mathrm{~g} / \mathrm{cc}-1.98 \mathrm{~g} / \mathrm{cc}$ and optimum

Moisture content (OMC) lies in between $24.97 \%$ to $37.24 \%$ and 5.02\%-14.67\%. But, AASHTO D-180 standard specification of the subgrade and sub base materials are MDD $\geq 1.76 \mathrm{~g} / \mathrm{cc}$ and MDD $2 \mathrm{~g} / \mathrm{cc}$ respectively. So, the subgrade and the sub base laboratory results under the specification.

\section{California Bearing Ratio}

California Bearing Ratio (CBR) is a measure of shearing resistance of the material under controlled density and moisture conditions. The test consisted of causing a cylindrical plunger of $50 \mathrm{~mm}$ diameter to penetrate a pavement component material at $1.25 \mathrm{~mm} / \mathrm{minute}$. The loads for $2.54 \mathrm{~mm}$ and $5.08 \mathrm{~mm}$ were recorded. This load is expressed as a percentage of standard load value at a respective deformation level to obtain CBR value.

Table 6: Three point California bearing ratio (CBR) test results

\begin{tabular}{|c|c|c|c|c|c|c|c|c|c|c|c|c|c|}
\hline \multirow{4}{*}{$\begin{array}{l}\text { Level of Damage) } \\
\text { High }\end{array}$} & \multirow{4}{*}{ Station } & \multicolumn{6}{|c|}{ Sub-grade layers } & \multicolumn{6}{|c|}{ Sub-base layer } \\
\hline & & \multicolumn{3}{|c|}{$2.54 \mathrm{~mm}$} & \multicolumn{3}{|c|}{$5.08 \mathrm{~mm}$} & \multicolumn{3}{|c|}{$2.54 \mathrm{~mm}$} & \multicolumn{3}{|c|}{$5.08 \mathrm{~mm}$} \\
\hline & & \multicolumn{3}{|c|}{ No. of blows } & \multicolumn{3}{|c|}{ No. of blows } & \multicolumn{3}{|c|}{ No. of blows } & \multicolumn{3}{|c|}{ No. of blows } \\
\hline & & 10 & 30 & 65 & 10 & 30 & 65 & 10 & 30 & 65 & 10 & 30 & 65 \\
\hline \multirow{5}{*}{$\begin{array}{c}\text { deterioration } \\
\text { (More severe) }\end{array}$} & $0+920$ & 3.6 & 4.2 & 4.2 & 3.2 & 4.1 & 4.3 & 13.2 & 18.1 & 19.2 & 6.0 & 9.6 & 10.4 \\
\hline & $3+740$ & 3.4 & 3.5 & 4.1 & 3.6 & 4.2 & 3.9 & 13.9 & 18.3 & 29.4 & 6.1 & 10.1 & 9.8 \\
\hline & $6+720$ & 3.2 & 3.4 & 4.3 & 3.1 & 3.8 & 4.2 & 14.5 & 17.9 & 18.6 & 9.4 & 11.6 & 7.9 \\
\hline & $9+420$ & 3.9 & 3.2 & 4.2 & 3.3 & 3.7 & 4.8 & 14.1 & 18.2 & 19.0 & 8.2 & 10.7 & 12.6 \\
\hline & Average & 3.5 & 3.6 & 4.2 & 3.3 & 4.0 & 4.1 & 13.9 & 18.1 & 21.5 & 7.7 & 10.0 & 10.2 \\
\hline \multirow{7}{*}{$\begin{array}{l}\text { Medium deterioration } \\
\text { (Severe) }\end{array}$} & $0+020$ & 3.2 & 4.1 & 4.5 & 3.1 & 3.8 & 4.2 & 4.8 & 8.3 & 20.2 & 6.5 & 16.2 & 12.5 \\
\hline & $3+160$ & 3.1 & 3.3 & 4.9 & 3.3 & 3.7 & 4.8 & 3.2 & 8.6 & 28.7 & 6.4 & 17.6 & 11.2 \\
\hline & $4+240$ & 3.5 & 3.6 & 4.7 & 3.2 & 4.1 & 4.3 & 6.2 & 8.5 & 29.2 & 6.3 & 15.2 & 14.6 \\
\hline & $5+500$ & 3.6 & 3.7 & 4.9 & 3.6 & 4.2 & 3.9 & 3.7 & 8.9 & 28.4 & 6.8 & 14.6 & 15.3 \\
\hline & $7+740$ & 3.4 & 3.6 & 4.8 & 3.3 & 3.7 & 4.2 & 6.6 & 8.2 & 21.6 & 6.2 & 18.2 & 13.9 \\
\hline & $9+720$ & 4.2 & 4.2 & 4.7 & 3.6 & 4.9 & 4.2 & 6.8 & 8.7 & 28.6 & 6.3 & 10.7 & 12.1 \\
\hline & Average & 3.6 & 3.8 & 4.6 & 2.9 & 3.7 & 4.1 & 4.4 & 8.5 & 26.1 & 6.4 & 15.4 & 13.3 \\
\hline \multirow{6}{*}{$\begin{array}{l}\text { Low deterioration (Low } \\
\text { severe) }\end{array}$} & $1+840$ & 3.6 & 4.4 & 4.7 & 3.4 & 4.5 & 4.6 & 7.1 & 7.1 & 10.1 & 6.6 & 18.2 & 10.2 \\
\hline & $2+160$ & 4.6 & 4.1 & 4.8 & 3.2 & 3.7 & 3.9 & 7.9 & 10.6 & 19.8 & 6.5 & 19.6 & 14.5 \\
\hline & $4+300$ & 4.2 & 4.2 & 4.9 & 2.6 & 3.6 & 3.6 & 6.3 & 7.4 & 29.6 & 6.9 & 17.5 & 19.3 \\
\hline & $7+820$ & 2.9 & 3.4 & 4.8 & 4.1 & 3.9 & 3.7 & 6.5 & 9.8 & 20.4 & 6.8 & 20.6 & 16.4 \\
\hline & $9+140$ & 3.8 & 4.2 & 4.9 & 3.5 & 3.5 & 4.7 & 7.8 & 6.2 & 21.3 & 6.7 & 18.3 & 20.4 \\
\hline & Average & 4.2 & 3.3 & 4.8 & 2.6 & 3.8 & 4.2 & 7.1 & 9.6 & 22.2 & 6.7 & 18.8 & 16.1 \\
\hline \multicolumn{2}{|l|}{ Total Average } & 3.9 & 4.1 & 4.5 & 3.5 & 3.9 & 4.3 & 7.4 & 8.7 & 23.3 & 6 & 14 & 13.2 \\
\hline
\end{tabular}

The average CBR test values of high, medium and low deterioration (sever) of sub base results are 21.5, 26.1 and 22.24 respectively .But, AASHTO T-193 specification for the standard minimum requirement for sub base indicate as 30\% (CRR $\geq 30 \%)$ table and also the average value of subgrade soil laboratory test results were 4.2,4.6 and 4.82 at High, Medium and Low Deterioration .But, ERA specification for the standard minimum requirement for sub base indicate as $5 \%(\mathrm{CRR} \geq 5 \%)$.From the point of view the CBR value of laboratory test of sub base and subgrade materials are under the specification 


\section{CONCLUSIONS}

After identify the distress and categorized the level of severity sample extracted and conducted laboratory tests. The following conclusions are drawn:-

$>$ The subgrade and the sub base materials are poor graded because of weak compaction, high void and moisture fluctuation. Since this moisture fluctuation can be affected or washed out of the fine ingredient and the materials can't interlock each other.

$>\mathrm{NMC}$ greater than OMC because of excess air and water in the sub grade and sub base materials it tends to keep particle apart.

$>$ The sub grade and sub base layers of the studied stretch should not compact well and not achieve at least a relative density of $95 \%$.

$>$ The subgrade and the sub base materials are poor strength or unsuitable for road construction as a result the sub base materials can't carry the base course because low CBR value from the standard specification.

The measure causes of deterioration can be excess water, poor materials, lack of proper drainage, lack of drainage, lack of routine and timely maintained, seepage and infiltration of water in to pavement layers, poor compaction (poor method of compaction). These can be cause of deteriorations.

$>$ But, The Atterberg's limit tests of the sub-base and subgrade materials were observed in the laboratory satisfy the standard specification.

\section{RECOMMENDATION}

Based on the above conclusion the following recommendations are drawn:

The sub base and the subgrade materials should be properly selected properly compacted at least a relative density of $95 \%$ of MDD achieved by heavy compaction and adequate shoulder constructed unless too much money invested for maintenance.
$>$ Asphalt surface adequate surface or subsurface drain, run out and protection should be provided. Seal coats shall be applied to prevent infiltration and seepage of water through cracked surfaces to different layers of the pavement.

$>$ The possible recommended remedial measure of edge cracking type deformations are elimination of excess moisture by building shoulder and providing proper drainage with good materials important to enhance both serviceability and structural capacity levels.

$>$ The subgrade and the sub base layers of materials are Poor strength (CBR) this is not suitable for road construction. So, either removed unsuitable materials and replace suitable materials or maintenance and rehabilitation alternative.

The voids beneath of the pavement should be filled with high soften under sealing asphalt to prevent the intrusion of water in to the subgrade and sub base.

The problem of the subgrade drainage, the attention must be given to ground water pumping, seepage and water infiltration that needs in depth geochemical investigation.

\section{REFERENCES}

1. Behanu, G. (2005) ECNG 635 Pavement material (3) Lecture Note.

2. Daniel Tilahunpaulos. (2004) Influence on drainage condition on shear strength parameters of expansive soils. Addis Ababa University, Addis Ababa Ethiopia.

3. ERA (2002), Pavement Rehabilitation and Asphalt over lay manual.

4. ERA,(2002) Pavement design manual volume 1, chapter 3 subgrade Brehanenaselam printing enterprise, Addis Ababa.

5. Ethiopia roads authority standard manuals. Jimma road project. 